\title{
Aktivita a tvořivost v Maňákově pojetí a jeho pedagogické činnosti ${ }^{1}$
}

\author{
Vlastimil Švec \\ Masarykova univerzita, Pedagogická fakulta, Katedra pedagogiky \\ Redakci zasláno 21. 8. 2014 / upravená verze obdržena 27. 10. 2014 / \\ k uveřejnění přijato 29. 10. 2014
}

\begin{abstract}
Abstrakt: Cílem studie je charakterizovat Maňákovo pojetí aktivity a tvořivosti a nastínit, jak se toto pojetí projevuje $\mathrm{v}$ jeho pedagogické činnosti. V její první části je charakterizováno Maňákovo pojetí aktivity a tvořivosti. Druhá část si všímá kořenů tohoto pojetí a třetí se pokouší ukázat toto pojetí v jeho pedagogické činnosti. Zjištění plynoucí z kvalitativní analýzy lze shrnout do několika tezí. Jádrem Maňákova pojetí je triáda pojmů aktivita - samostatnost (samostatná práce) - tvořivost žáků. J. Maňák dospěl na základě svých výzkumů k tzv. principu postupnosti, který vyjadřuje požadavek, aby aktivita, samostatnost a tvořivost byly u žáků rozvíjeny postupně a respektovaly žákovy možnosti. Maňákovo pojetí aktivity a tvořivosti má kořeny již $\mathrm{v}$ období, kdy byl žákem, a dále v jeho teoretické, badatelské, ale i výukové činnosti. Promítá se do jeho pedagogického působení, které je založeno na Maňákových tacitních pedagogických znalostech a zkušenostech.
\end{abstract}

Klíčová slova: aktivita, tvořivost, samostatná práce, Maňákovo pojetí aktivity a tvořivosti, princip postupnosti, tacitní znalosti

Aktivitu a tvořivost považujeme za významné atributy výchovně-vzdělávacího procesu. Toto konstatování není nové a objevuje se poměrně často v pedagogické teorii i praxi. $V$ literatuře nalezneme různé teoretické koncepce aktivity a tvořivosti, které se vyvíjely v historickém kontextu výchovy a vzdělávání a jsou spojeny s výraznými představiteli pedagogiky. Právem k nim patří i Josef Maňák, emeritní profesor brněnské pedagogické fakulty.

Nebývá př́liš obvyklé hledat zdroje teoretických koncepcí aktivity a tvořivosti u představitelů pedagogické teorie a ještě méně je obvyklé hledat spojení mezi těmito koncepcemi a pedagogickým působením jejich autorů. V literatuře publikované koncepce aktivity a tvořivosti jsou totiž většinou přijímány jako

1 Studie byla finančně podpořena GA ČR v rámci řešení grantového projektu 13-20049S Osvojování tacitních znalostí studenty učitelství v průběhu jejich pedagogické praxe. 
objektivizované výsledky teoretického studia a výzkumů jejich představitelů, byt' se mohou vyvíjet a měnit. Kromě toho je z hlediska metodologického obtížné nalézat paralely mezi pedagogickými teoriemi a pedagogickým působením jejich autorů. Do povědomí pedagogických odborníků vstupují většinou jen teorie jejich představitelů.

Cílem tohoto textu je charakterizovat Maňákovo pojetí aktivity a tvořivosti, poodhalit jeho kořeny a pokusit se nalézt odraz tohoto pojetí v pedagogické činnosti J. Maňáka. Budeme hledat odpovědi na tři základní otázky:

1. Čím se vyznačuje Maňákovo pojetí aktivity a tvořivosti žáků?

2. Jaké jsou kořeny tohoto pojetí?

3. Jak se toto pojetí promítá do pedagogické činnosti J. Maňáka?

Charakter těchto otázek umožnil volbu kvalitativního postupu našeho pátrání po Maňákově pojetí aktivity a tvořivosti, který spočíval v analýze dostupných, jeho již publikovaných prací a odpovědí J. Maňáka na otázky předložené v písemné podobě. Využili jsme těchto zdrojů:

(a) vybraných studií J. Maňáka k problematice aktivity, samostatnosti a tvořivosti (Maňák, 1998; Maňák, 2001; Maňák, 2003);

(b) písemně zaznamenaných dialogů s J. Maňákem (Švec, 2003);

(c) písemných odpovědí J. Maňáka na otázky autora tohoto textu, které byly položeny a zodpovězeny v červnu-červenci 2014 (takto vzniklé krátké texty dále označujeme Maňák1 a Maňák2). V textu Maňák1 profesor volně charakterizuje svoje současné, zobecněné a globální pojetí aktivity a tvořivosti, v textu Maňák2 dotazovaný odpovídá na tři otázky:

Které myšlenky z Tvého pojetí aktivity a tvořivosti považuješ za nadčasové pro pedagogickou teorii a praxi?

Když se zpětně zamýšlíš nad svým pojetím aktivity a tvořivosti, napadá Tě něco, co sis možná dříve neuvědomoval?

Jak jsi usiloval o aplikaci svého pojetí aktivity a tvořivosti do vlastního pedagogického působení na školách, kde jsi vyučoval? 
(d) vybraných blahopřání a medailonků k výročím J. Maňáka (Spousta, 2009; Jůva, 2009; Rýdl, 2009; Ries, 2009; Pol \& Rabušicová, 2009; Pelikán, 2009; Švec, 2005).

Při analýze obsahu citovaných textů jsme vycházeli z uvedených otázek 1-3. Protože texty vznikaly v různé době a s rozdílným posláním, vraceli jsme se opakovaně k jejich obsahu.

\section{Charakteristika Maňákova pojetí aktivity a tvořivosti žáků}

Své pojetí aktivity a tvořivosti zakládá Maňák na důsledném vymezení klíčových pojmů. Aktivitu a tvořivost (žáků) vymezuje v různých publikacích. Všimneme si tohoto vymezení v monografii Rozvoj aktivity, samostatnosti a tvořivosti žáků (Maňák, 1998).

Aktivitou ve výuce Maňák rozumí „zvýšenou, intenzivní činnost žáka, a to jednak na základě vnitřních sklonů, spontánních zájmů, emocionálních pohnutek nebo životních potřeb, jednak na základě uvědomělého úsilí, jehož cílem je osvojit si př́slušné vědomosti, dovednosti, návyky, postoje nebo způsoby chování“ (Maňák, 1998, s. 29). Tvořivost pak chápe jako „přirozené vlastnosti člověka (různé síly a zaměřenosti) projevující se seberealizací individua při vzniku něčeho nového, kterou je potřeba rozvíjet, připravovat jí prostor a potlačovat bariéry, které se jí stavějí do cesty“ (Maňák, 1998, s. 74).

Z uvedených komplexních vymezení obou pojmů vyplývá, že aktivitu a tvořivost lze ve vzdělávání probouzet, podporovat a rozvíjet, samožrejmě v rámci individuálních možností žáků, různými formami samostatné práce. Samostatnou práci žáků J. Maňák (1998, s. 41) vymezuje jako „takovou učební aktivitu, při níž žáci získávají poznatky a dovednosti vlastním úsilím, relativně nezávisle na cizí pomoci a cizím vedení, a to zejména řešením problémů“.

Triáda aktivita-samostatnost-tvořivost tvoří u Maňáka základ pro teoretické a výzkumné rozpracovávání této, pro pedagogickou praxi závažné problematiky. Maňák výzkumy potvrdil, že jde o tři psychické procesy, které však spolu souvisejí. Aktivita je předpokladem samostatnosti a spolu s ní směřuje k tvořivosti. Ve výuce jde o to, postupně rozvíjet tvořivost žáků, která předpokládá také postupný rozvoj jejich aktivity a samostatnosti (Maňák, 1965). Tento požadavek lze označit jako princip postupnosti. 
Samotný autor k tomu uvádí:

Jeden z výsledků mého bádání, na němž jsem si jako na originálním př́nosu poněkud zakládal, se týkal fázování jednotlivých aktivit žáků a jejich postupně se zeslabujícího řízení učitelem, čímž vznikly takzvané stupně žákovské samostatnosti. Šlo o dynamickou strukturu výukové interakce zacílenou na rozvíjení žákových schopností, při níž se v kontrární reciprocitě zvyšovala žákovská samostatnost a snižovalo učitelovo vedení. (Maňák, 1993, s. 30-31)

Maňák aktivitu, samostatnost a tvořivost rozlišil do několika stupňů tak, aby je bylo možné ve školní praxi diagnostikovat. Vymezil tyto stupně (viz např. Maňák, 1998, s. 80-81; Maňák, 2001, s. 21):

- aktivity: vynucená, navozená, nezávislá a angažovaná;

- samostatnosti: napodobující, reprodukující, produkující a přetvářející;

- tvořivosti: expresivní (spontánní), inovativní (spojena se záměrným úsilím něco netradičního udělat), inventivní (spojena s uměleckými artefakty, vědeckými a technickými objevy apod.) a emergentní (vznik zcela nových artefaktů a jevů).

Je zřejmé, že jednotlivé stupně aktivity a samostatnosti představují kvalitativně vyšší úrovně. U tvořivosti má ale stupňovitost poněkud jiný charakter, je v ní sice zachován postupný nárůst kvality, ale zároveň vyjadřuje různé formy tvořivého výkonu (Maňák, 1997, s. 17).

Vymezení těchto stupňů Maňák doplnil názorným schématem (viz obr. 1). Vznikly tak tři stupnice, které ověřoval - po podrobné instruktáži učitelů ve školní praxi.

Ale neuspěl jsem. Většina učitelů nebyla schopna ani metodicky připravené stupně na chování žáků aplikovat. ... Prostě učitelé většinou žáky klasifikovali a nesnažili se proniknout ke specifice sledovaného fenoménu a uplatnit vědeckou metodu pozorování. (Švec, 2003b, s. 31) 


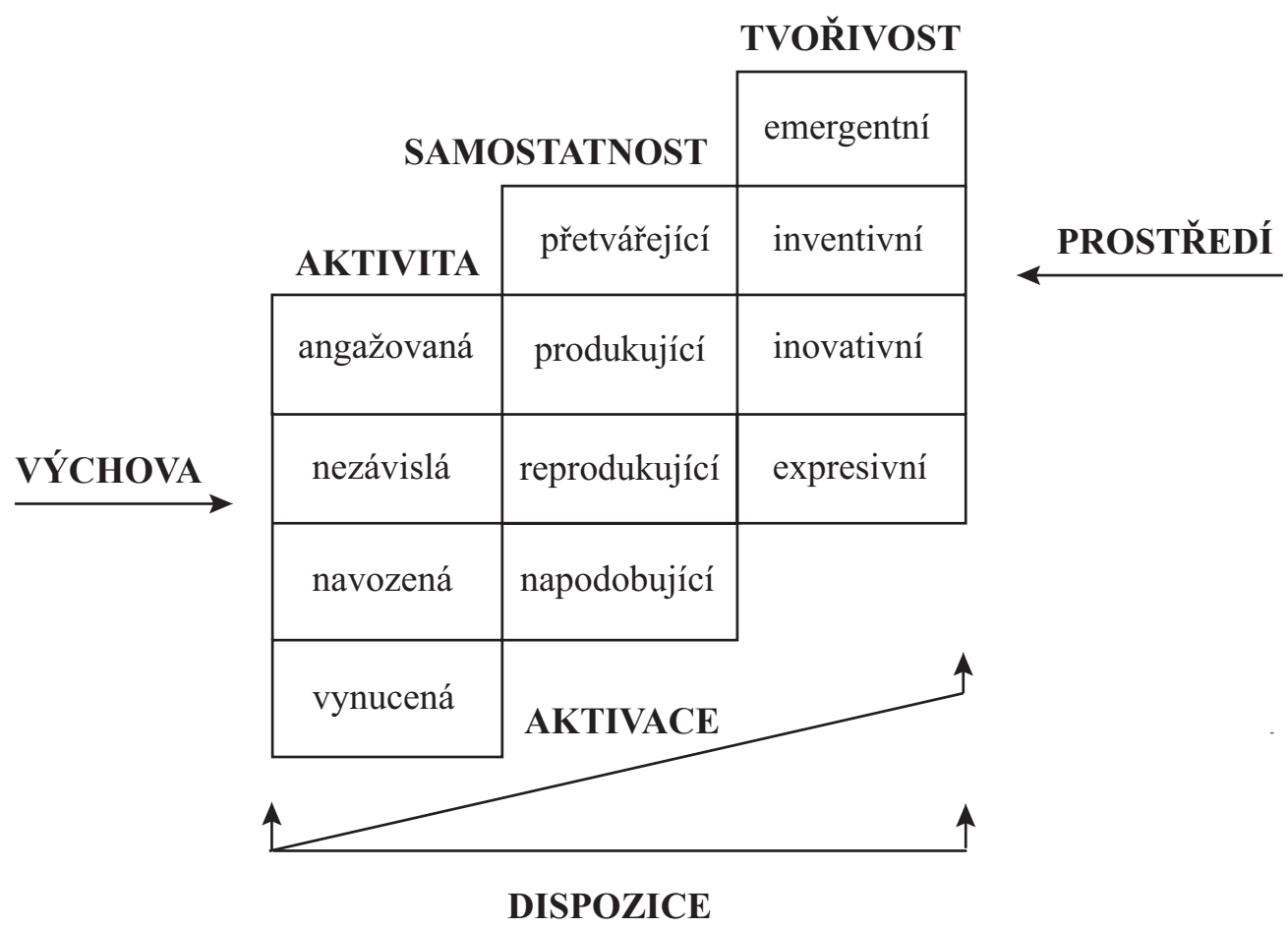

Obrázek 1. Stupně rozvoje aktivity, samostatnosti a tvořivosti žáků (Maňák, 2001, s. 21).

Maňák dospěl $\mathrm{k}$ poznatku, že chce-li učitel podněcovat a rozvíjet tyto žákovské projevy, měl by umět rozpoznat tvořivého člověka:

Ovšem abych si uvědomil, že mám před sebou tvořivého člověka, musím se s ním nebo s jeho prací hlouběji seznámit a nechat na sebe jeho postoje, dílo, koncepce, myšlenky působit. Tvořivý člověk většinou ve mně vyvolá pozornost, překvapení, údiv, nebot' mi nabízí nový pohled na věc, který mě zaujme, obohatí. [...] Tvořivý člověk připoutává mou pozornost nejen svou nápadností, ale často i v drobnostech, které mě něčím osloví. Většinou se projevuje výrazným zaujetím, angažovaností, často se vyznačuje zacílenou kritičností svědčící o přesném postižení problému. (Švec, 2003, s. 28-29)²

2 Je zřejmé, že diagnostika projevů aktivity a samostatnosti a úrovně tvořivosti žáků zahrnuje řadu diagnostických dovedností učitele. To si Maňák uvědomil a k této problematice publikoval samostatné studie (Maňák, 2000; Maňák, 2002). Současně však připravil pro učitele stručnou, ale názornou metodiku tvořivé práce (Maňák, 2001). 
Z této výpovědi je zřejmé, že Maňák směřuje ke kvalitativním postupům poznávání lidské tvořivosti, a to přesto, že dnes již existují různé testy a dotazníky tvořivosti. Tyto výzkumné nástroje sice umožní „změřit“ např. úroveň tvořivých schopností a vlastnosti jedince, avšak obvykle nepostihují jeho osobnost jako celek.

Uvedené pojmy a princip postupnosti lze považovat za jádro Maňákova pojetí aktivity a tvořivosti žáků. $Z$ tohoto jádra vychází i jeho koncepce aktivizujících výukových metod. Podle Maňáka každá výuková metoda může, byt' v různé míře, žáky aktivizovat; přece jen však lze vyčlenit metody, které ve zvýšené míře podněcují žákovu samostatnost a tvořivost - aktivizující metody. Patří k nim: metody diskusní, metody heuristické spojené s řešením problémů, metody situační, metody inscenační a didaktické hry (Maňák, 2003a).

Jak s odstupem řady let J. Maňák pohlíží na své pojetí aktivity a tvořivosti?

Význam a dosah koncepce aktivity, samostatnosti a tvořivosti jsem si plně uvědomil, až jsem jako učitel zvládl pedagogickou praxi a pronikl též do pedagogické teorie. Potom už jsem ovšem neměl mnoho př́ležitostí pokračovat v praxi, začal jsem se víc pohybovat $\mathrm{v}$ teorii. Zpočátku jsem se také domníval, že když bude mít učitel teoreticky jasno, že to bude přenášet do své výchovně-vzdělávací praxe. Zjistil jsem však, že to neplatí jednoznačně. Teorie a praxe musí jít souběžně, ale mnozí učitelé to nejsou s to realizovat. U žáků jde ovšem o praktickou činnost, její zaměření a vytváření podmínek. Souvisí to $s$ jejich předpoklady, fyzickými a psychickými, úrovní celkového rozvoje, jejich tvořivost má osobnostní rozměr: dosáhnout něčeho nového mohou jen na úrovni svého rozvoje. U dospělého člověka má vrchol jeho rozvoje - tvořivost, též sociální rozměr, tvořivé dílo musí uznat a přijmout společenství. Tvořivost je $\mathrm{u}$ žáků cílem, $\mathrm{k}$ němuž výchovněvzdělávací proces směřuje. Ovšem není záruka, že ho musí vždy dosáhnout. (Maňák2)

Současně si uvědomuje, že:

tvořivost je fenomén, podobně jako jiné výchovné cíle, který se s vývojem a výchovou člověka modifikuje, vždy však jde o objevování něčeho nového u žáka v oblasti a dosahu jeho dosaženého vývoje, u dospělého člověka v platnosti obecných požadavků společnosti. Rozvoj tvořivosti ve výchově je proto velmi složitý proces: cíl je sice jasný, ale pedagog jej musí chápat a zaměřovat $\mathrm{k}$ němu úsilí v daných podmínkách a okolnostech, a to z hlediska vývoje jedince. I mně to dlouho trvalo, než jsem složitost a náročnost vedení $\mathrm{k}$ tvořivosti plně pochopil. Je to však podstata výchovného procesu. Požadavky se sice odvozují od cíle, ale musí se vždy přizpůsobit dané situaci. To je výchova, v tom je její složitost a náročnost. (Maňák2) 
Z uvedených výpovědí lze odvodit tyto poznatky:

- K výše prezentovanému pojetí aktivity a tvořivosti dospěl J. Maňák postupně. Za východisko svého pojetí považuje pedagogickou praxi na školách, kde vyučoval, a také studium pedagogické teorie. Zjistil však, že neplatí jednoznačně teze „od pedagogické teorie k pedagogické praxi“, nebot' teorie a praxe se musí prolínat.

- J. Maňák si uvědomuje, že požadavek na rozvíjení tvořivosti žáků se sice jeví jako poměrně jednoduchý a jasný, avšak jeho realizace v praxi je mnohem složitější. Přiznává, že také jemu trvalo, než pochopil složitost tohoto požadavku, aby mohl ve škole vést žáky k tvořivosti.

- J. Maňák dospěl k přesvědčení, že poznání a respektování žákovy osobnosti je nezbytným předpokladem podněcování a rozvíjení jeho tvořivosti. A dále, že i když edukativním cílem je rozvoj tvořivosti žáků, není záruka, že tohoto cíle bude vždy dosaženo.

J. Maňák své pojetí aktivity a tvořivosti promýšlí i v současné době. Kriticky se např. vyjadřuje k novým přístupům k rozvoji samostatnosti žáků, např. $\mathrm{k}$ autonomii:

V současnosti přichází z USA (psychologové E. L. Deci a R. M. Ryan) další návazný nový pojem, a to autonomie, který v duchu moderního individualismu př́liš vyzvedává nezávislost a originalitu jedince. U nás jej začínají používat psychologové, kde je na místě, ale zajisté se dostane i do pedagogiky, kde může být špatně interpretován. Domnívám se, že pojem autonomie by neměl dominovat na úrovni aktivity a samostatnosti, poněvadž nemá tak obecnou platnost, neměl by převážit nad tvůrčím myšlením a ideálem harmonické osobnosti. (Maňák1) ${ }^{3}$

Publikační ohlasy na Maňákovy práce o aktivitě, samostatnosti a tvořivosti nejsou př́liš početné, protože v období tzv. normalizace (1979-1989) nesměl vyučovat ani publikovat. Avšak právě v této době dozrávaly jeho větší studie o této problematice, které však končily „V šuplíku“. ${ }^{4}$ Po roce 1989 sice vyšly (např. Maňák, 1992, 1996, 1997, 1998), ale odborná veřejnost již řešila jiné problémy. Přesto, že Maňákovo jméno zmizelo na tak dlouhou dobu z veřejného diskursu, jeho pojetí aktivity a tvořivosti zůstává aktuální

O autonomii a jejích výzkumech se již u nás začínají objevovat studie (Mareš \& Mareš, 2014). V této studii nalezne zájemce odkazy na další, zejména zahraniční literaturu.

4 Přes uvedené omezení se přesto podařilo J. Maňákovi publikovat některé studie (Maňák \& Švec, 1981; Švec \& Maňák, 1981). 
i dnes. Svědčí o tom mimo jiné jeho nedávné studie, které např. zdůrazňují potřebu rozšírit aktivizující metody v současné základní škole (Maňák, 2005) a poukazující na tvořivost učitelů při plánování a realizaci kurikula (Maňák, 2006), ale i obecnější studie o vztahu pedagogické teorie a praxe (Maňák, 2011).

\section{Kořeny Maňákova pojetí aktivity a tvořivosti}

Kořeny Maňákova pojetí aktivity a tvořivosti lze nalézt již v období, kdy byl žákem. Jako žák na sobě poznával dopady pedagogického reformismu, který stavěl na aktivitě a samostatnosti žáků.

Já jsem se s tímto pedagogickým proudem setkal v době, kdy jsem chodil do měštanské školy v Lipově v letech 1936-37. Škola vznikla v roce 1922 a jejím ředitelem se stal J. Úlehla, tehdy už v důchodu a nemocný. Přesto vtiskl škole pokrokový ráz ve smyslu reformismu, který tam silně přetrvával i v době, kdy jsem školu navštěvoval. Učili jsme se tam psát na stroji, vázat knihy, němčinu, ale hlavně se věnovala pozornost tělesné výchově. Každý den o velké přestávce jsme povinně za každého počasí cvičili (30 minut). Tento návyk mně zůstal dodnes. (Maňák1) ${ }^{5}$

Vliv lipovské školy rozvinul zřejmě u Maňáka jeho osobnostní rysy, k nimž patří také aktivita a samostatnost.

Byl jsem vždy, jako žák, student i učitel, aktivní, lipovská škola to ve mně posílila, teoreticky jsem si to uvědomil až později. Už jako student na gymnáziu jsem se tak stal přes své mládí knihovníkem studentské knihovny. Založil jsem a vydával časopis Psanec ... Z té doby pochází též můj „epos“ v časomíre „Tragédie všech věků" (ze studentského dávnověku). (Maňák2)

Osobnostní potenciál, který trvale ovlivňoval Maňákovo pojetí aktivity a tvořivosti, vyjádřili také jeho kolegové: „V Tobě je stále hravost a překvapivost dětství, hledání adolescentů, rozvážnost a přemýšlivost dospělosti, ale i pokora spojená s vlídnou moudrostí zralého věku“ (Pelikán, 2009, s. 256). Lze

\footnotetext{
Při studiu v Praze jsem chtěl psát doktorskou práci o Úlehlovi, ale prof. Hendrich, na kterého jsem se v této věci obrátil, mou snahu nepřijal s dotazem: „A mělo by to smysl?“ To mě na nějakou dobu odradilo pokračovat, ale nakonec jsem se jako učitel (1949-1960) a jako odb. asistent na UP v Olomouci (1960-1969) touto problematikou začal zabývat soustavněji a napsal jsem o této problematice několik článků (Maňák1). Tady lze pozorovat Maňákův hlubší zájem o problémy samostatné práce žáků, ale také jeho nezdolnost, protože se od svých studijních plánů nenechal odradit.
} 
tedy předpokládat, že významným zdrojem Maňákova pojetí aktivity a tvořivosti se stala škola, at’ již se v ní pohyboval v roli žáka, studenta nebo později učitele.

Schopnost citlivě vnímat a reagovat na aktuální problémy školské praxe a nahlížet je z teoretických pozic se pak stává jedním z nejcharakterističtějších znaků všech jeho pozdějších studií. (Spousta, 2009, s. 239)

Problémům aktivity, samostatnosti a tvořivosti se věnoval J. Maňák v různých obdobích svého profesního vývoje. Toto téma si zvolil jako téma kandidátské disertační práce, jeho školitelem byl prof. Emil Stračár. Inspirovaly ho také četné studie k problematice samostatné práce žáků. „Této problematice jsem zůstal věrný i v habilitační práci, kterou jsem obhájil v r. 1969, a přitahuje mne dosud" (Švec, 2003, s. 32).

Kromě soustavného studia literatury k otázkám aktivity a samostatné práce žáků začal J. Maňák také s výzkumy.

Ve spolupráci s ochotnými učiteli jedné olomoucké školy jsem připravil a realizoval longitudinální výzkum samostatné práce žáků, v němž jsem se pokusil srovnáváním experimentálních a kontrolních tříd prokázat účinnější výsledky samostatné práce žáků. (Švec, 2003, s. 32)

Již jen z uvedených výpovědí lze s určitou nadsázkou ř́ci, že problematika aktivity, samostatnosti a tvořivosti žáků se stala osudovým tématem J. Maňáka. Provází jej totiž celým profesním životem.

\section{Maňákovo pojetí aktivity a tvořivosti $v$ jeho pedagogické činnosti}

Pedagogická činnost J. Maňáka zahrnuje zejména jeho pedagogické působení, ale také jeho učební texty, popř. další artefakty, např. písemné poznámky $\mathrm{k}$ přednáškám a seminářům, prezentace pro výuku apod. Problematika aktivity, samostatnosti a tvořivosti žáků je objasňována v řadě jeho učebních textů (Maňák, 1996; Maňák, 2003b; Maňák et al., 1992; Maňák et al., 1997). Tyto texty se vyznačují jednoduchým, ale věcným vyjadřováním, do kterého se promítá Maňákovo pojetí aktivity a tvořivosti, které jsme charakterizovali v 1. části naší studie. 
Zjištovat Maňákovo pojetí aktivity a tvořivosti v jeho pedagogickém působení není jednoduché. Do pedagogického jednání se totiž promítají také Maňákovy schopnosti, pedagogické zkušenosti a znalosti. Maňákovy pedagogické znalosti mají tacitní charakter. ${ }^{6}$ Zahrnují složku kognitivní, která je patrná již ve zmiňovaném jeho pojetí aktivity a tvořivosti. Druhou základní komponentou tacitních znalostí je složka nonkognitivní, k níž patří např. zájem J. Maňáka o výuku, jeho motivace prohlubovat svoje pedagogické znalosti, radost z komunikace se studenty a kolegy apod. A třetí složkou jsou tělové (tedy i řečové) projevy tacitních znalostí v pedagogických situacích. Tato složka představuje určitý přechod mezi tacitní a explicitní dimenzí pedagogických znalostí.

Na nonkognitivní složku tacitních znalostí lze usuzovat z výpovědí jejich nositele - J. Maňáka:

Učil jsem vždy rád. [...] dobře jsem se cítil na gymnáziu. [...] Spolu se studenty jsme pořádali různé akce, např. jsem inicioval nejrůznější kroužky... (Švec, 2003, s. 15). Ve výuce jsem studenty aktivizoval tím, že jsem je vyvolával k vyjádření, když se nehlásili a o práci neměli zájem. [...] Na základní škole, kam jsem přešel, protože jsem byl unaven dojížděním, jsem založil též turistický kroužek, který si žáci velmi oblíbili, takže jsem se jich ani nemohl zbavit, když jsem přešel na univerzitu do Olomouce. (Maňák2)

O projevech tacitních znalostí J. Maňáka (v jejich explicitní podobě) vypovídají také jeho žáci a kolegové. Popisují např. způsob aktivizace J. Maňákem: „V seminářích z obecné didaktiky nám Dr. J. Maňák zadává úkoly pro přípravu referátu na zvolené téma, pro malý didaktický průzkum na škole... Učíme se v něm vyslovovat vlastní názory, diskutovat a přemýšlet" (Švec, 2003, s. 5). Pokoušejí se také o hlubší vhled do Maňákova pedagogického působení: „Pozorovat Tě při pedagogických ,exhibicích' je požitkem, nebot' se sice držíš předem promyšlené logické osnovy, ale dovedeš také improvizovat a přivést k pozornosti někdy již (např. v závěru přednášky) unavené publikum“ (Švec, 2005, s. 205).

Pedagogické působení J. Maňáka však nezahrnuje pouze jeho výuku, ale i další aktivity, např. referáty na konferencích, workshopy, semináře, komunikaci s kolegy apod. Jeho kolegové si zřejmě proto uvědomují širší dosah Maňákova pedagogického působení. K. Rýdla fascinuje Maňákova „vitalita a tvůrčí

6 O tacitních znalostech podrobněji pojednáváme v samostatných studiích (Švec, 2012; Šíp \& Švec, 2013). 
aktivita, kterou by mohl zastiňovat mladší kolegyně a kolegy, ale on ji využívá k vytváření prostoru pro ně, pro jejich vlastní činnost a odborný růst“ (Rýdl, 2009, s. 249). Pro V. Jůvu je J. Maňák nadšeným učitelem a člověkem. „V pedagogické práci, kterou chápe jako setkávání, vzájemné obohacování a podněcování, se mu vždy daří vytvářet náročnou, ale současně pozitivní a optimistickou atmosféru..." (Jůva, 2009, s. 244). Také M. Pol a M. Rabušicová upozorňují na pedagogické působení pana profesora na vysoké škole: „Připočítáme-li k tomu, že je Josef Maňák úspěšným a jak víme také oblíbeným vysokoškolským učitelem, musíme se ptát, kde hledat zdroj takového pracovního elánu. [...] nejspíše to bude $\mathrm{v}$ tom, že ho prostě jeho práce pořád baví a naplňuje“ (Pol \& Rabušicová, 2009, s. 245).

Zdá se, že tacitní, skrytá oblast Maňákovy osobnosti představuje něco víc než jen jeho pedagogické znalosti, zkušenosti a schopnosti. Výstižně to vyjádřil Minkowski: „Všechny naše činy jsou jakoby neseny něčím neuchopitelnějším, méně určitým, celkovějším, co nelze rozebrat na izolované prvky. Jsou zaplaveny tím, co vyzařuje $\mathrm{z}$ osobnosti jako celku, a osobnost tento moment nedokáže odlišit, upřesnit ani si jej jasně uvědomit" (Minkowski, 2011, s. 105).

\section{Závěr}

Cílem naší studie bylo charakterizovat Maňákovo pojetí aktivity, (samostatnosti) a tvořivosti a naznačit, jak se toto pojetí promítá do jeho pedagogické činnosti. Jádrem Maňákova pojetí je poznatek, že rozvoj tvořivé osobnosti žáků se realizuje postupně v triádě aktivita-samostatnost-tvořivost. Postupný nárůst projevů tvořivé osobnosti by měl být podle J. Maňáka jedním ze stěžejních cílů současné školy. Připomíná však, že:

[...] zejména u pojmu tvořivost je třeba být u rozvíjejícího se jedince opatrný, protože proces tvořivosti se u něho vyvíjí v souladu s jeho výbavou i celkovým rozvojem a na každé úrovni má jiný ráz a projev. I přes obtíže je však nutno tímto směrem pokračovat a také připravovat $\mathrm{k}$ vnímání a usměrňování tohoto vrcholného lidského projevu učitele. Mnozí světoví myslitelé (např. A. Einstein aj.) nás tímto směrem orientují. Měl by to být charakteristický rys školy nové doby. (Maňák1)

Je zřejmé, že Maňákovo pojetí aktivity a tvořivosti má komplexnější charakter, dotýká se obsahu, metod i forem vzdělávání, žákova učení a učitelova vyučování (i když v naší studii jsme všechny tyto složky zcela nepostihli). 
Maňákovo pojetí vychází z jeho osobních zkušeností v roli žáka i studenta a později učitele na různých stupních škol. Je neustále prohlubováno studiem literatury a opírá se o jeho četné výzkumy. Uvedené jádro pojetí aktivity a tvořivosti se však prŕliš nemění.

Současně s teoretickým utvářením a vyzráváním pojetí aktivity, samostatnosti a tvořivosti žáků se J. Maňák zamýšlí nad jeho realizací ve škole. Je přesvědčen, že dnešní škola umožňuje princip postupného rozvíjení aktivní, samostatné a tvořivé práce žáků uskutečňovat. „Ovšem tak, že se nebude o aktivitě, samostatnosti a tvořivosti jen vznešeně hovořit, ale že se bude prakticky provádět v běžných činnostech žáků“ (Maňák2).

I když je Maňákovo pojetí aktivity a tvořivosti založeno také na psychologických přístupech, je jako celek orientováno výrazně pedagogicky. Toto pojetí se pohybuje na kontinuu od praxe $\mathrm{k}$ teorii a zpět od teorie k praxi.

Z Maňákova pojetí vyplývá, že rozvoj aktivity, samostatnosti a tvořivosti žáků předpokládá aktivního a tvořivého učitele, který dovede tyto stupně rozvoje žákovy osobnosti podněcovat, řídit a diagnostikovat.7 Také nabývání těchto dovedností, které začíná již ve studiu učitelství, má postupný charakter a vyžaduje tedy integrované kurikulum, $\mathrm{v}$ němž dochází $\mathrm{k}$ přirozenému propojování pedagogické teorie a praxe. To klade vyšší nároky na současné vzdělavatele učitelů.

Z našeho textu vyplývá, že Maňákovo pojetí aktivity a tvořivosti se promítá do jeho pedagogické činnosti. Odhalit a konkretizovat uvedené konstatování však není jednoduché. Dospěli jsme k poznatku, že pedagogické působení J. Maňáka sice jeho žáci a studenti i kolegové pocitují (a procitují), avšak jeho kořeny jsou tacitní.

Naši studii můžeme uzavřít konstatováním, že $\mathrm{v}$ odborném, vědeckém a pedagogickém, ale i osobním životě Josefa Maňáka se již od jeho mládí projevovala touha poznávat, tvořivě komunikovat a řešit problémy. Tato touha spolu s radostí z tvořivých výsledků zejména jeho žáků charakterizuje pana profesora dodnes. Aktivita, samostatnost a tvořivost nepředstavují u J. Maňáka pouze základ jeho bádání a pedagogického působení, ale vyjadřují také (a to v neposlední řadě) jeho celoživotní postoj.

Zdá se, že v Maňákově pojetí dosud explicitně převažuje regulativní dimenze učitelova podněcování aktivity, samostatnosti a tvořivosti žáků. Avšak jeho pojetí samostatné práce předpokládá „práci žáka na sobě“, tzn. autoregulaci učení. Také výukovou metodu chápe Maňák spolu se Švecem jako regulaci a autoregulaci učení žáků (Maňák \& Švec, 2009, s. 194). 


\section{Literatura}

Jůva, V. (2009). Pedagogika potřebuje výjimečné osobnosti. Zdravice k významnému životnímu jubileu profesora Josefa Maňáka. In T. Janík \& V. Švec, et al., K perspektivám školního vzdělávání (s. 243-244). Brno: Paido.

Maňák, J. (1965). Problém postupnosti při řízení samostatné práce žáků. Jednotná škola, 9(1), $50-61$.

Maňák, J. (1992). Problém domácích úkolů na základní škole. Brno: Masarykova univerzita.

Maňák, J. (1993). Jak jsem objevil Ameriku. In J. Malina, et al., O tvořivosti ve vědě, politice a umění III. (s. 30-31). Brno: Masarykova univerzita.

Maňák, J. (1996). Rozvoj aktivity, samostatnosti a tvořivosti žáků. In Vybrané kapitoly z obecné didaktiky (s. 25-31). Brno: Masarykova univerzita.

Maňák, J. (1997). Proces výchovy k tvořivosti. In Tvořivostí učitele k tvořivosti žáků (s. 15-18). Brno: Paido.

Maňák, J. (1998). Rozvoj aktivity, samostatnosti a tvořivosti žáků. Brno: Masarykova univerzita.

Maňák, J. (2000). Dovednost diagnostikovat tvořivé aktivity žáků. In V. Švec (Ed.), Monitorování a rozvoj pedagogických dovedností (s. 160-163). Brno: Paido.

Maňák, J. (2001). Stručný nástin metodiky tvořivé práce ve škole. Brno: Paido.

Maňák, J. (2002). Kompetence učitele pro diagnózu tvořivosti jako výrazné vlastnosti osobnosti žáka. In V. Švec, et al., Cesty k učitelské profesi: utvárení a rozvíjení pedagogických dovedností (s. 203-207). Brno: Paido.

Maňák, J. (2003a). Aktivizující výukové metody. In J. Maňák \& V. Švec, Výukové metody (s. 105-130). Brno: Paido.

Maňák, J. (2003b). Nárys didaktiky. Brno: Masarykova univerzita.

Maňák, J. (2005). Hledání orientace moderní základní školy. In J. Maňák \& T. Janík (Eds.), Orientace české základní školy (s. 21-28). Brno: Masarykova univerzita.

Maňák, J. (2006). Determinanty kurikula. In J. Maňák \& T. Janík (Eds.), Problémy kurikula základní školy (s. 23-28). Brno: Masarykova univerzita.

Maňák, J. (2011). K problému teorie a praxe v pedagogice. Pedagogická orientace, 21(3), 257-271.

Maňák, J., \& Švec, V. (1981). K rozvoju samostatnej práce žiakov. Jednotná škola, 33(3), 246-261.

Maňák, J., \& Švec, V. (2009). Formy a metody výuky. In J. Průcha (Ed.), Pedagogická encyklopedie (s. 194-199). Praha: Portál.

Maňák, J., et al. (1992). Profesionální praktika z pedagogiky. Brno: Masarykova univerzita.

Maňák, J., et al. (1997). Alternativní metody a postupy. Brno: Masarykova univerzita.

Mareš, J., \& Mareš, J. (2014). Autonomie dospívajícího jedince: složitý proces, nejistý výsledek. Pedagogika, 64(1), 81-97.

Minkowski, E. (2011). Vstříc kosmologii. Praha: Malvern.

Pelikán, J. (2009). Řeka života. In T. Janík \& V. Švec, et al., K perspektivám školního vzdělávání (s. 256-257). Brno: Paido.

Pol, M., \& Rabušicová, M. (2009). Džentlmenu naší pedagogiky. In T. Janík \& V. Švec, et al., K perspektivám školního vzdělávání (s. 245). Brno: Paido.

Ries, L. (2009). Profesor Josef Maňák. In T. Janík \& V. Švec, et al., K perspektivám školního vzdělávání (s. 250-251). Brno: Paido. 
Rýdl, K. (2009). Zamyšlení nad životním jubileem profesora Josefa Maňáka. In T. Janík \& V. Švec, et al., K perspektivám školního vzdělávání (s. 249). Brno: Paido.

Spousta, V. (2009). Josefu Maňákovi k významnému životnímu výročí. In T. Janík \& V. Švec, et al., K perspektivám školního vzdělávání (s. 239-242). Brno: Paido.

Šíp, R., \& Švec, V. (2013). Pojetí tacitních znalostív paradigmatu sjednoceného pole. Pedagogická orientace, 23(5), 664-690.

Švec, V. (2003). Životní cesta jako proces výchovy a sebevýchovy. Dialogy s Josefem Maňákem nejen o pedagogice. Brno: Konvoj.

Švec, V. (2005). K jubileu prof. Josefa Maňáka. Pedagogická revue, 57(2), 203-206.

Švec, V. (2012). Tacitní znalosti jako most mezi teorií a praxí v pedagogické př́ípravě budoucích učitelů. Pedagogická orientace, 22(3), 387-403.

Švec, V., \& Maňák, J. (1981). Uplatnenie problémových metód vo vzdelávaní dospelých. Osvetová práca, 31(7), 9-12.

\section{Autor}

prof. PhDr. Vlastimil Švec, CSc., Masarykova univerzita, Pedagogická fakulta, Katedra pedagogiky, Poříćí 31, 60300 Brno, e-mail: svec@ped.muni.cz

\section{Maňák's approach to activity and creativity and its reflection in his educational practice}

Abstract: This paper aims to introduce Maňák's approach to activity and creativity and describe how this approach is reflected in his educational practice. The first part characterizes his approach, the second part explores its roots, and the third part tries to identify it in his educational practice. The qualitative analysis can be summarized in several points. The core of Maňák's approach is the following triad: activity independence - creativity. Based on his research, Maňák formulates the principle of gradual development of activity, independence and creativity, and posits that this process should respect the individual abilities of the pupils. The roots of Mańák's approach lie in the time when he was a pupil himself and in his theoretical, research, and teaching activities. It is reflected in his educational practice, which is based on his tacit educational knowledge and experience.

Keywords: activity, creativity, independence, Maňák's approach to activity and creativity, principle of gradual development, tacit knowledge 